\title{
The Effect of Relative Standing on Considerations
}

\section{About Self-Employment}

\author{
Stefan Schneck*
}

December 14, 2011

\begin{abstract}
This paper uses unique German data to examine the effects of the relative standing on the individual propensity to become self-employed in the next two years. The results suggest that the relationship between relative wage positions and propensity to become self-employed is U-shaped. This is interpreted as evidence that low status translates into entrepreneurial motivation for workers in low relative wage positions. Employees with high relative standing, in turn, seem to be more concerned about the lack of future career prospects in paid employment and consider self-employment as a next step on the individual career ladder.
\end{abstract}

JEL-Classification: L26, L29

Keywords: Relative wage position, status, self-employment

\footnotetext{
${ }^{*}$ Corresponding author: Stefan Schneck, Institute for SME Research Bonn. Maximilianstraße 20, 53111 Bonn, Germany, e-mail: schneck@ifm-bonn.org. I have benefited from discussions with Rosemarie Kay, Peter Kranzusch, and Arndt Werner. Thanks to participants of the G-Forum 2011 and RENT XXV conference for valuable comments.
} 


\section{Introduction}

Magnitudes of papers have examined the outcomes of self-employment with a special focus on monetary rewards. Individual utility, however, is not solely determined by pecuniary aspects. In fact, the results presented in Hamilton (2000) suggest that there are substantial nonpecuniary benefits of self-employment. Benz and Frey (2008) described that individuals derive utility from independence in self-employment. Ryan and Deci (2000) showed that self-determination can be characterized by the degree of autonomy, individual competence, and need to be respected within social groups. This paper contributes to the question of how individual prestige in paid employment affects the decision to become self-employed. The own relative standing and income comparisons have reached attendance in studies on interdependent preferences and subjective well-being (see, e.g., Hamermesh, 1975; Frank, 1985; Easterlin, 1995; Clark and Oswald, 1996; Clark et al., 2008) as well as in papers on economic behavior (see, e.g., Pfeifer, 2010).

Card et al. (2010) analyzed the impact of relative standing on satisfaction with the job and the probability of looking for a new job. ${ }^{1}$ Pfeifer and Schneck $(2011,2012)$ argued that job mobility is negatively correlated with individual utility and showed that direct mobility between establishments is affected by relative wage positions. As self-employment can be viewed as an alternative to mobility between jobs, similar arguments are expected to hold for the propensity to become self-employed in the near future. Growing number of studies on nascent entrepreneurship which aim to improve the understanding of individual start-up efforts (Davidsson, 2006) are revealing the importance of this particular strand in the literature. Although status is considered to be an important factor in entrepreneurial motivation (Carsrud and Brännback, 2011), the literature lacks an analysis of how current relative standing in paid employment affects individual start-up efforts. This paper fills the gap by analyzing the relationship between relative wage positions in paid employment

\footnotetext{
${ }^{1}$ The authors also provide a more comprehensive survey of the literature on relative pay comparisons.
} 
and the motivation to become self-employed.

Using unique German panel data, this study has contributed empirical findings to the effects of comparison income on the propensity to become self-employment among German males aged between 19 and 55 years. The sample comprised 7,211 observations on 4,308 blue- and white-collar workers in the periods 1999, 2001, 2003, 2005, 2007, and 2009. A significant U-shaped effect with respect to the relative wage position was found to be evident. In the context of the literature on relative wage positions, this can be explained in the way in which workers at the bottom of the wage distribution have concerns about their low status, and therefore, are planning to become self-employed. Workers in high positions, in turn, suffer few career advancement opportunities at the current employer and might consider self-employment as a possibility to improve their own career. This explanation approach, which basically relies on individual utility, is supported by the finding that an inverse U-shaped relationship is evident when utilizing job satisfaction as the dependent variable. For this reason, the analysis also shows that the assumptions of Pfeifer and Schneck (2011) are reasonable in the context of self-employment.

The paper proceeds as follows. In the next section, the main hypotheses are introduced and the theoretical background is discussed. Section 3 describes the data set and the imposed restrictions. Section 4 presents and interprets the empirical findings, while Section 5 provides the conclusion.

\section{Theoretical Background and hypotheses}

Standard economic literature explains that individual utility is mainly determined by absolute wages, whereas increasing wages increase individual utility. This paper, however, refers to relative wage positions that rely on income comparisons with an individually defined reference group. Other peoples' income is a remarkably important determinant in studies 
on subjective well-being (Clark et al., 2008). If the own wage is held constant, lower wages of comparable individuals might increase individual utility because it allows for downward comparisons which might be perceived as of high status (status effect). Among a bulk of studies, Clark et al. (2008) corroborated that higher relative wage positions increase the well-being. However, the relative wage position can also provide information about own future prospects (Hirschman and Rothschild, 1973; Clark et al., 2008; Card et al., 2010). In other words, the higher the relative wage position is, the lower is the future advancement opportunities, because one is already high up in the pay scale. Higher comparison income, thus, might reduce individual utility if the individual obtains utility from career advancement opportunities. The literature refers to this kind of upward comparison as the signal effect, because other individuals provide a signal about the own fortune in the future. For a more detailed discussion on the status and signal effect, one can refer to Clark et al. (2009), in which the authors also present evidence in favor of the signal effect.

This analysis aims to describe whether good fortune of the reference group introduces jealousy (status effect) or increases individual utility by signaling bright future career prospects (signal effect). Note that status effect and signal effect are contradictory, because workers in high relative wage positions have high status, but few career advancement opportunities. For workers in low relative wage positions, the reverse is true. Most studies only refer to the average effect of the relative standing in the considered samples which allows to conclude about whether, on average, the status effect or the signal effect is dominant. As the effects of relative wage positions on the start-up effort are ambiguous, this paper contributes an analysis of the effect of relative wage positions on the propensity to become self-employed. The paper also goes beyond the scope of most of the studies because of the specially focus on individuals in very low and very high relative positions. This is important because individuals with lowest relative standing are not able to obtain any utility from status while those in the highest positions do not obtain utility from 
signal. For this reason, the paper analyzes whether status or signal are more important in these positions. So far, most of the studies refer to linear effects, which, however, might be misinterpreted if one group obtains utility primarily from status and another group accumulates utility basically from signal within the sample. Thus, the linear effects only indicate which of the effects, on average, are dominant in the whole sample, and do not refer to possible heterogeneity within the sample.

In order to address the consideration above as well as the established literature on the effects of relative wage positions, two main hypotheses are derived which basically rely on an inverse relationship between the propensity to become self-employed and individual utility. The nonlinear relationship in hypothesis 2 allows for the possibility that workers at the top and workers at the bottom evaluate the status effect and the signal effect in a different manner.

1. Linear effects:

(a) Are workers in high relative wage positions more satisfied because of high status and, as a consequence, less concerned about future self-employment? In this case, the status effect dominates the signal effect.

(b) Are workers in high relative wage positions less satisfied because of low future career prospects? Then, workers with high standing are more engaged in becoming self-employed. The signal effect, then, dominates the status effect.

\section{Nonlinear effects:}

(a) Is the relationship between relative wage positions and the propensity to become self-employed U-shaped? In this case, workers with low relative standing are more concerned about status, and thus consider self-employment as an exit from low status, while workers in high relative wage positions suffer few career prospects that outweigh the high status of these workers. 
(b) Is the propensity to become self-employed in the near future inversely U-shaped with respect to the relative wage position? This would imply that workers in low relative wage positions are less concerned about self-employment because of greater career prospects, while workers in high relative positions are less engaged to become self-employed because of their high status.

So far, the paper has only addressed the aspect of prestige within social groups, and has not referred to the remaining determinants of self-determination as cited by Ryan and Deci (2000). The present study accounts for the individual competence by examination of different hierarchical levels of workers. Workers with allowance for guidance, however, might be less concerned about self-employment because of the permission to control coworkers, although it is reasonable to expect that even workers at the highest hierarchical levels are subject to instructions and are not completely self-determined in firms. This effect might be counteracted by an opposing human capital effect. Specifically, workers in high hierarchical positions are usually familiar with managerial tasks, and acquire competence about leading departments or whole companies, which subsequently alleviates self-employment. Individual autonomy is, to some extent, addressed by the size of the firm, because Wagner (1997) had showed that employees in smaller firms tend to have lower institutional possibilities to participate in the decision making process. Less participation also restricts individual autonomy within a firm. Larger firms, in turn, are characterized by a more decentralized process of decision making, which allows for more individual autonomy. Entrepreneurship, moreover, is accompanied by opportunity costs of being self-employed, when compared with being employed (Amit et al., 1995). Such effects are accounted for by inclusion of the current wage. Controlling for the absolute wage also accounts for the effect that absolute compensation also contributes to individual's utility. 


\section{$3 \quad$ Data and methodology}

The analysis of relative wage positions and self-employment is at the early stages of development, because it is problematic to find any data that contain information on entrepreneurial motivation, individual reference groups, and individual wages. The Gründerpanel of the Institute for Small Business Research in Bonn (Kranzusch and Kay, 2011) or the Global Entrepreneurship Monitor data (Brixy et al., 2011) lack detailed information on individual wages. $^{2}$ Matched employer-employee data, such as the linked employer-employee data set of the Institute for Employment Research(Jacobebbinghaus, 2008), include direct information on colleagues as reference group and wages, but lack information on the start-up effort. The German Socio-Economic Panel (GSOEP; see Wagner et al., 2007) has been utilized in this study because it contains wage-related information, questions on the intension to become self-employed, and job-specific characteristics, which have been applied to generate comparison groups. As a result, the data allowed for the analysis of the effects of relative wage positions in the decision process of becoming self-employed.

The underlying data set only focuses on male German citizens in blue- and white-collar jobs. The study on males is reasoned by the fact that income comparisons seem to be more important for the subjective well-being of males, when compared with females (Mayraz et al., 2009). In addition, labor market participation issues are reduced when only focusing on males. The data have been further restricted to individuals between 19 and 55 years of age. The upper bound is reasoned in the short amortization period of self-employment for older individuals. As a consequence, older individuals might be more concerned about (early) retirement than about self-employment. The lower bound has been chosen because schooling degrees are usually achieved at this age. For information related to individual wages, the GSOEP questionnaire has been employed, which asks respondents about their

\footnotetext{
${ }^{2}$ Both data sets include questions on the household income or wages, respectively. The variables, however, are categorized and therefore not adequate for the analysis of relative wage positions.
} 
monthly earnings from work in the last month. It must be noted that this study has only focused on workers with a gross wage of at least 400 Euro in the last month. ${ }^{3}$

The variable of main interest in this study refers to the future self-employment. The original question in the wave 2003 is as follows: How likely is it that the following career changes will take place in your life within the next two years?

- have become self-employed and/or freelance, and/or self-employed professional?

Subsequently, the respondents have to reply based on an eleven-item ordinal scale ranging from zero (definitely not) to 100 (definitely). Note that this question was included in the GSOEP questionnaire in the waves 1999, 2001, 2003, 2005, 2007, and 2009. In the consecutive analysis, this variable has been used as the indicator for the intension to become self-employed and as the dependent variable.

\section{Insert Figure 1 about here}

The following brief descriptive part is to introduce the underlying data. First, dummy variables were assigned to individuals who indicated affiliation to a particular wage quintile in year $t$. Figure 1 illustrates that the highest wage earners (in wage quintiles four and five) have the highest motivation to become self-employed, followed by the workers with lowest wages (in wage quintiles one and two). The Figure demonstrates a U-shaped relationship with respect to the relative wage position, and therefore, is in line with hypothesis $2 \mathrm{a}$. On an average, the smallest start-up effort has been observed in wage quintile three. However,

\footnotetext{
${ }^{3}$ Original question (changes slightly over time): How high were your earnings from work last month? Do not include any special payments you may have received last month such as vacation bonuses or back pay, but do include pay for overtime. If possible, please give both: your gross earnings, i.e., your pay before taxes and social contributions are taken out; and your net earnings, i.e., the amount you receive after taxes and contributions for pension plan, unemployment and health insurance. The consumer price index surveyed by the Sachverständigenrat zur Begutachtung der gesamtwirtschaftlichen Lage is applied to deflate the nominal wages $(Z R \quad 084 ; 2005=100)$. Wages in 1999 and 2001 are divided by 1.95583 because the questionnaire refers to wages in DM instead of Euro.
} 
it must be noted that the intention to become self-employed is very small in the sample. The average propensity to become self-employed in the data is 8.93 (see Table 4), and thus, the clear tendency towards not becoming self-employed at all is evident.

Literature on wage comparisons suggests that individuals compare themselves most likely with colleagues (Clark and Senik, 2010) who are not identifiable in the data. Mayraz et al. (2009) also utilized the GSOEP and showed that individual comparisons within professions are important. Based on this finding, in the present study, it has been assumed that workers compare themselves to workers with similar tasks. This reference group is, however, a very crude one. Table 1 shows the definition of low, medium, and high positions account for hierarchical differences and professional tasks. Based on these hierarchical positions, measures indicating the relative wage position of individual $i$ in period $t$ by hierarchical position pos have been generated.

\section{Insert Table 1 about here}

Self-determination might also be affected by the firm size. Wagner (1997) showed that smaller firms tend to have a more centralized decision making process, when compared with large companies. This reduces autonomy considerably and might increase the startup effort of workers, especially in smaller firms. Therefore, four categories indicating the workforce have been defined, which are assumed to characterize firm-specific differences. A detailed description of these categories is presented in Table 2. Accordingly, this information has been used to define the relative wage positions of worker $i$ in period $t$, position pos, and firm with workforce $f$ size. ${ }^{4}$

Insert Table 2 about here

\footnotetext{
${ }^{4}$ This categorization allows for enough wage variation within groups. Only 71 observations are available for workers in low hierarchical positions employed in companies with more than 2000 workers. Most observations (834) are on individuals in medium hierarchical positions working in firms with more than 20 and less than 200 employees. Separation by sector would not allow for any wage variation in some industries which is the main reason for applying firm size instead of sectors. Low observations by federal regions (Bundesländer) induces similar problems.
} 
Table 3 describes the measures for the relative wage position of individual $i$ in wave $t$ which have been applied in the following multivariate analysis. The measures for the relative wage positions have been defined in analogy to Pfeifer and Schneck (2012) and Brown et al. (2008). The main difference is that the rank accounts for the ordinal distance across workers, while the range accounts for the cardinal wage difference between worker $i$ in period $t$ and the lowest wage earner in period $t$. That is, workers are sorted in an ascending series in accordance to their absolute wages. While the rank only takes account of the position, the range also considers wage differentials across individuals in Euro. As the measures for the relative standing might be affected by the sheer number of observations and outliers in period $t$, respectively, both variables have been normalized to lie within the unit interval. However, individuals in rank (range) zero have been observed to have the lowest relative standing in period $t$, while employees in rank (range) one occupy the highest relative wage position. Note that workers may not know the exact wages of other workers: "All we can say is that people act as though they are able to form a reasonable estimate of where, as individuals, they lie in the pay ordering and the range" (Brown et al., 2008, p. 379).

\section{Insert Table 3 about here}

To consider the ordinal nature of the dependent variable, ordered probit estimation was conducted to conclude about the effects of the relative standing. The prevalence of individualspecific effects was tested by the application of the Breusch-Pagan Lagrange multiplier test (Breusch and Pagan, 1979), which is based on linear regression models, instead of ordered probit models. The null hypothesis of no individual heterogeneity was rejected at the 1 percent level for all specifications. For this reason, unobserved heterogeneity was controlled for by application of the random-effects ordered probit estimator (Greene, 2011, Chapter 18). A large set of control variables was included to control for age, individual human capital (tenure, educational degrees), labor market status (dummy variable for blue-collar 
workers), part-time work (dummy variables for working hours), unemployment, marital status, annual effects, and regional effects. As already discussed earlier, opportunity costs of self-employment were accounted for by the current wage. To account for the different levels of autonomy in paid employment, the effects for different sizes of companies were controlled for. Individual competence was modeled by dummy variables for different hierarchical positions. Table 4 presents the descriptive statistics of the variables included in the multivariate analysis by hierarchical positions.

Insert Table 4 about here

\section{Results}

This section consists of two parts. The first part describes how relative wage positions affect intensions to become self-employed while the second part examines the effect of relative wage positions on satisfaction with the job. Table 5 refers to the linear effects mentioned in Hypotheses 1a and 1b. Although statistically insignificant, all specifications presented a negative coefficient for the rank and range measures, which can be interpreted in the way that higher relative wage positions lower the propensity to quit a job for self-employment in the near future. The results, thus, are in favor of Hypothesis 1a, where the status effect is the predominant one. Higher relative standing introduces satisfaction because of high status, which, then, is expected to decrease the propensity to become self-employed in the near future.

The dummy variables for low and medium positions were negative, but not significant in all specifications. This implies that workers in low and medium positions are less likely to become self-employed in the near future, when compared with workers in high hierarchical positions with allowance for guidance and managerial tasks. On the one hand, this can be explained with human capital, because already obtained managerial skills are expected 
to alleviate self-employment. On the other hand, workers also might seek for even more competence in the sense of controlling the environment, although workers in high positions already have allowance for guidance. The coefficients for the size of the firm, which are used as proxy for autonomy, revealed that workers in smaller firms exhibit higher effort to become self-employed than those in large companies with more than 2,000 workers. ${ }^{5}$ This shows that less autonomy increases considerations about self-employment. Basically, the results are in line with Benz and Frey (2008) who discuss the importance of individual independence in self-employment. With respect to the components of self-determination in Ryan and Deci (2000) this implies that workers consider self-employment as an exit of low perceived autonomy, of subjectively underrated individual competence, and of low status within social groups. The effect of observed wages of individual $i$ in period $t$ was found to be positive and statistically significant in specifications (1) and (4). Opportunity costs, however, might play a minor role in planning self-employment which is also supported by the statistical insignificance in specifications (2) and (3).

Insert Table 5 about here

The analysis of possible nonlinearities, presented in Table 6 revealed a more distinctive picture, when compared with those presented in Table 5. The quadratic specifications adverted to a U-shaped relationship between relative wage positions and the propensity to become self-employed, which translated into an insignificantly negative effect in the linear specifications. Note that the log likelihood of the nonlinear models are slightly smaller in absolute values, indicating that these models fit the data better. The effects of competence (positional dummy variables), autonomy (workforce dummy variables), and

\footnotetext{
${ }^{5}$ Note that, according to Boden (1996), employees of small firms were more likely to switch to selfemployment than employees of large firms, which might be indicative of (indirect) entrepreneurial learning. In this line, Storey (1994) argued that presumably larger firms offer fewer entrepreneurial role models. However, this negative relationship between the size of the firm and probability of switching into selfemployment might also reflect more favorable working conditions in larger firms in terms of earnings and security to keep the job.
} 
$w_{i t}$ were relatively robust, when compared with those presented in Table 5 . An exception is the estimated coefficient for workers in low positions because this effect was positive in specification (1) of Table 6 and negative in specification (1) of Table 5. In addition, the coefficients for $w_{i t}$ were statistically significant in all specification of Table 6 .

\section{Insert Table 6 about here}

With regard to the effects of the relative wage positions, the results suggest a significant U-shaped relationship. The results, thus, are in line with Hypothesis 2a. Workers in low relative wage positions are found to be more concerned about their low status, which, in turn, increases the likelihood of self-employment. Employees with high relative standing seem to be more concerned about the lack of future career prospects in paid employment and consider self-employment as a next step on the individual career ladder. The corresponding minimum values of the presented specifications in Table 6 are $0.73\left(r a n k_{i t, p o s}\right)$, $0.62\left(\right.$ rank $\left._{i t, p o s, f s i z e}\right), 0.73$ (range $\left._{i t, p o s}\right)$, and $0.60\left(\right.$ range $\left._{i t, p o s, f s i z e}\right)$. This implies that workers who are able to conduct downward comparisons (more than half of the workers have lower relative standing) and, in addition, have some career advancement opportunities (there is still a considerable share of workers in higher positions) exhibit the lowest start-up effort.

In sum, the results show that lower autonomy and more centralized decision making processes in smaller firms increase individual start-up effort. Competence, the second major determinant of self-determination mentioned by Ryan and Deci (2000), is shown to affect entrepreneurial motivation such that workers with managerial tasks even try to obtain more control via self-employment. This result is also in line with the hypothesis that managerial tasks and the allowance for guidance in paid employment alleviate selfemployment. The main focus of this study is on the analysis of how relative wage positions affect the propensity to become self-employed. The insignificant evidence in favor of a linear status effect stems from a more distinctive relationship because it has been shown that both status as well as signal matter when planning to become self-employed. Precisely, 
the nonlinear specifications show that workers in middle wage position are less concerned about self-employment, while those in high and low positions exhibit higher start-up effort. The results, thus, are in line with Hypothesis 2a.

The U-shaped relationship between start-up effort and relative wage positions is in line with the one reported in the study of Pfeifer and Schneck (2011) that analyzed direct mobility between establishments. The authors argued that mobility is negatively correlated with individual utility and stated that individuals obtain utility from both status as well as signal. The explanation approach in this paper is based on the similar argument that the propensity to become self-employed stems from low utility (dissatisfaction) with the current job and, thus, is an inverse measure for utility. The GSOEP has included information on satisfaction with the job, which is frequently used as proxy for individual utility, because Freeman (1978) showed its importance as an economic variable. The data, thus, is adequate to examine whether the assumption of an inverse relationship between the propensity to become self-employed and utility is a reasonable one. ${ }^{6}$

When using the propensity to become self-employed in the near future as an inverse indicator for satisfaction with the job, workers in the middle relative wage positions (ranging from 0.60 to 0.73 ) should be most satisfied with their jobs. As argued earlier, workers at the bottom of the wage distribution might be concerned about their relative standing, which, then, might introduce dissatisfaction (i.e., low utility) with the current job. The lack of career advancement opportunities, in turn, might translate into low satisfaction with the job for workers at the top of the wage distribution. Subsequently, random-effects ordered probit estimation was conducted where individual satisfaction with the job was utilized as the dependent variable to prove the validity of these hypotheses. Note that 40

\footnotetext{
${ }^{6}$ In the GSOEP questionnaire, individuals are asked to report their job satisfaction in each year. Satisfaction with the job, then is rated on a scale from 0 (low) to 10 (high). The original question in 1999 is: How satisfied are you today with the following areas of your life? Please answer by using the following scale: 0 means totally unhappy and 10 means totally happy. How satisfied are you with (if employed) your job?
} 
observations have were dropped from the analysis because of non-response. The BreuschPagan Lagrange multiplier test adverted to individual effects at the 1 percent level. Hence, individual random-effects ordered probit estimation was applied.

\section{Insert Table 7 about here}

The results for the linear effects of the relative wage positions are presented in Specifications (1) to (4) in Table 7 . The estimated coefficients were non-robust across specifications because Specification (3) describes that workers in higher positions are less satisfied with their jobs. This is in favor of the signal effect, but should not be overemphasized because of the statistical insignificance. Specifications (1), (2), and (4) exhibit positive coefficients for the relative wage position, which is in favor of the status effect. Workers in higher relative positions seem to be more satisfied with their jobs. According to Specifications (4) to (8), presented in Table A.3, an inverse U-shaped effect is shown for the relative wage positions. This result supports the main assumption that the start-up effort is likely to be an inverse measure for satisfaction with the job. Note that, the effect of range $_{i t, p o s}$ is not statistically significant, whereas range $_{i t, p o s}^{2}$ is significant in Specification (7). ). To answer the hypothesis that the most satisfied workers could be found in the relative wage positions within 0.60 and 0.73 , the corresponding maximum values of measures for the relative standing were calculated. The corresponding effects of $r a n k_{i t, p o s}, r_{a n k} k_{i t, p o s, f s i z e}$, range $_{i t, p o s}$, and range $_{i t, p o s, f s i z e}$ reveal maximums at $0.61,0.65,0.58$, and 0.84 , respectively. Thus, the explanation that workers who are most satisfied with the job are less likely to plan self-employment is supported. Furthermore, the assumptions used to derive the hypotheses, which basically rely on satisfaction with the job, are found to be reasonable.

Finally, Table 7 allows to discuss the results of Benz and Frey (2008) with respect to the determinants of self-determination presented in Ryan and Deci (2000). With respect to the need to be respected within social groups, the measures for the relative wage positions adverted to complex effects because workers with very low relative standing and workers 
in very high relative positions obtain lower utility in the job than workers who are able to conduct upward as well as downward comparisons. The effect of the degree of autonomy did not reveal any distinctive relationship with job satisfaction. Individual competence, which is approximated by hierarchical positions, showed that workers without allowance for guidance were significantly less satisfied when compared with those performing managerial tasks. Lastly, it is to note that the absolute wage was positive in all of the presented specifications, but was, in terms of statistical significance, of more importance in the equations with job satisfaction as dependent variable.

\section{Conclusion}

This study employed unique German data to examine the effect of relative wage positions on the propensity to become self-employed in the next two years. It has been found that workers in middle relative wage positions are less likely to become self-employed, when compared with those in high and low relative wage positions. However, the reverse can be observed when using satisfaction with the job as the dependent variable. This contradictory result allows for an explanation with respect to individual utility. Precisely, workers in low positions have concerns about their status, which reduces utility and increases the likelihood of self-employment. Employees with high relative standing, in turn, lack career advancement opportunities, which reduce utility and increase start-up effort.

To conclude, this paper enhances the literature about the early stages of self-employment in a considerable way because it contributes empirical findings to the question of whether and how comparison income matters in planning future self-employment. The main results of this study are that the status effect as well as signal effect are evident when deciding to become self-employed in the near future. Further research, however, is needed to conclude whether these effects are observable in other countries. Recently, Atolia and Prasad 
(2011) find that preferences for status increase self-employment because preferences for relative wealth lead to the willingness to take risks. An empirical analysis on the relationship between risk-taking and relative wage positions, thus, might contribute additional improvements in understanding individual start-up efforts. A further promising field of research is the analysis of how comparison income affects realized self-employment. 


\section{References}

Amit, R., Muller, E. and Cockburn, I. (1995). Opportunity costs and entrepreneurial activity. Journal of Business Venturing 10: 95-106.

Atolia, M. and Prasad, K. (2011). Relative wealth concerns and entrepreneurship. Economica 78: 294-316.

Benz, M. and Frey, B. S. (2008). Being independent is a great thing: Subjective evaluations of self-employment and hierarchy. Economica 75: 362-383.

Boden, R. J. (1996). Gender and self-employment selection: An empirical assessment. The Journal of Socio-Economics 25: 671-682.

Breusch, T. S. and Pagan, A. R. (1979). A simple test for heteroscedasticity and random coefficient variation. Econometrica 47: 1287-1294.

Brixy, U., Hundt, C., Sternberg, R. and Vorderwülbecke, A. (2011). Global Entrepreneurship Monitor (GEM): Länderbericht Deutschland 2010. Hannover/ nürnberg, Global Entrepreneurship Research Association.

Brown, G. D. A., Gardner, J., Oswald, A. J. and Qian, J. (2008). Does wage rank affect employees' well-being? Industrial Relations 47: 355-389.

Card, D., Mas, A., Moretti, E. and Saez, E. (2010). Inequality at Work: The Effect of Peer Salaries on Job Satisfaction. NBER Working Papers 16396, National Bureau of Economic Research, Inc.

Carsrud, A. and Brännback, M. (2011). Entrepreneurial motivations: What do we still need to know? Journal of Small Business Management 49: 9-26. 
Clark, A. E., Frijters, P. and Shields, M. A. (2008). Relative income, happiness, and utility: An explanation for the easterlin paradox and other puzzles. Journal of Economic Literature 46: 95-144.

Clark, A. E., Kristensen, N. and Westergård-Nielsen, N. (2009). Job satisfaction and coworker wages: Status or signal? Economic Journal 119: 430-447.

Clark, A. E. and Oswald, A. J. (1996). Satisfaction and comparison income. Journal of Public Economics 61: 359-381.

Clark, A. E. and Senik, C. (2010). Who compares to whom? the anatomy of income comparisons in europe. Economic Journal 120: 573-594.

Davidsson, P. (2006). Nascent entrepreneurship: Empirical studies and developments. Foundations and Trends in Entrepreneurship 2: 1-76.

Easterlin, R. A. (1995). Will raising the incomes of all increase the happiness of all? Journal of Economic Behavior \& Organization 27: 35-47.

Frank, R. H. (1985). Choosing the right pond. Oxford University Press, New York.

Freeman, R. B. (1978). Job satisfaction as an economic variable. American Economic Review 68: 135-41.

Greene, W. (2011). Econometric Analysis, 7. Prentice Hall.

Hamermesh, D. S. (1975). Interdependence in the labour market. Economica 42: 420-29.

Hamilton, B. H. (2000). Does entrepreneurship pay? an empirical analysis of the returns to self-employment. Journal of Political Economy 108: 604-631. 
Hirschman, A. O. and Rothschild, M. (1973). The changing tolerance for income inequality in the course of economic development; with a mathematical appendix. The Quarterly Journal of Economics 87: 544-66.

Jacobebbinghaus, P. (2008). LIAB-Datenhandbuch, Version 3.0. FDZ Datenreport. Documentation on Labour Market Data 200803-de, Institut für Arbeitsmarkt- und Berufsforschung (IAB), Nürnberg (Institute for Employment Research, Nuremberg, Germany).

Kranzusch, P. and Kay, R. (2011). Das Gründerpanel des IfM Bonn - Konzeption und Nutzungsmöglichkeiten. IfM-Materialien 208, Institut für Mittelstandsforschung, Bonn (Institute for Small Business Research, Bonn).

Mayraz, G., Wagner, G. G. and Schupp, J. (2009). Life Satisfaction and Relative Income: Perceptions and Evidence. IZA Discussion Papers 4390, Institute for the Study of Labor (IZA).

Pfeifer, C. (2010). Impact of wages and job levels on worker absenteeism. International Journal of Manpower 31: 59-72.

Pfeifer, C. and Schneck, S. (2011). Nonlinear effects of comparison income in quit decisions: Status and signal!, mimeo.

Pfeifer, C. and Schneck, S. (2012). Relative wage positions and quit behavior: Evidence from linked employer-employee data. Industrial and Labor Relations Review 65.

Ryan, R. M. and Deci, E. L. (2000). The "what" and "why" of goal pursuits: Human needs and the self-determination of behavior. Psychological Inquiry 11: 227-68.

Storey, D. J. (1994). Understanding the small business sector. London and New York: Routledge. 
Wagner, G. G., Frick, J. R. and Schupp, J. (2007). The german socio-economic panel study (soep) - scope, evolution and enhancements. Schmollers Jahrbuch: Journal of Applied Social Science Studies 127: 139-169.

Wagner, J. (1997). Firm size and job quality: A survey of the evidence from germany. Small Business Economics 9: 411-425. 


\section{Tables included in the text}

Table 1: Definition of low, medium, and high hierarchical positions.

\begin{tabular}{|c|c|c|c|}
\hline & $\begin{array}{l}\text { Low } \\
\text { positions }\end{array}$ & $\begin{array}{l}\text { Medium } \\
\text { positions }\end{array}$ & $\begin{array}{l}\text { High } \\
\text { positions }\end{array}$ \\
\hline Blue-collar & $\begin{array}{l}\text { Unskilled } \\
\text { workers }^{i}\end{array}$ & $\begin{array}{l}\text { Semi-skilled and } \\
\text { skilled workers }{ }^{i i i}\end{array}$ & $\begin{array}{l}\text { Foreman, } \\
\text { Master }^{v}\end{array}$ \\
\hline White-collar & $\begin{array}{lr}\text { Workers } & \text { with } \\
\text { simple } & \text { tasks } \\
\text { (with } & \text { and } \\
\text { without } & \text { vo- } \\
\text { cational training } \\
\text { degrees) }^{i i}\end{array}$ & $\begin{array}{l}\text { Workers in quali- } \\
\text { fied jobs }\end{array}$ & $\begin{array}{l}\text { Workers with } \\
\text { managerial tasks } \\
\text { or allowance for } \\
\text { guidance }^{v i}\end{array}$ \\
\hline German terms & $\begin{array}{l}\text { i) ungel- } \\
\text { ernte Arbeiter } \\
\text { ii) Angestellte } \\
\text { einfache } \\
\text { Tätigkeiten } \\
\text { mit/ohne Ausbil- } \\
\text { dungsabschluss }\end{array}$ & $\begin{array}{l}\text { iii) angelernte } \\
\text { Arbeiter, gel- } \\
\text { ernte Arbeiter } \\
\text { und Facharbeiter } \\
\text { iv) Angestellte } \\
\text { mit qualifizierter } \\
\text { Tätigkeit }\end{array}$ & $\begin{array}{l}\text { v) Vorarbeiter, } \\
\text { Kolonnen- } \\
\text { fuehrer, Meis- } \\
\text { ter, Polier } \\
\text { vi) Industrie- } \\
\text { und Werkmeis- } \\
\text { ter, Angestellter } \\
\text { mit hochqual- } \\
\text { ifizierter } \\
\text { Tätigkeit und } \\
\text { Leitungsbefug- } \\
\text { nis, Angestellter } \\
\text { mit umfassenden } \\
\text { Führungsauf- } \\
\text { gaben }\end{array}$ \\
\hline Number of observations & 634 & 4,169 & 2,408 \\
\hline
\end{tabular}


Table 2: Workforce classifications.

\begin{tabular}{lcccc}
\hline \hline Firm size & 1 & 2 & 3 & 4 \\
Workforce $_{i t}$ & $<20$ & {$[20 ; 200[$} & {$[199 ; 2000[$} & $\geq 2000$ \\
Number of observations & 1,571 & 2,213 & 1,665 & 1,762 \\
\hline \hline
\end{tabular}


Table 3: Definition of variables for relative wage position.

\begin{tabular}{|c|c|c|c|}
\hline & $\begin{array}{l}\text { By position } \\
\text { (see Table } 1)\end{array}$ & $\begin{array}{c}\text { By position and workforce } \\
\text { (see Tables } 1 \text { and 2) }\end{array}$ & \\
\hline$w_{i t}$ & \multicolumn{2}{|c|}{$\ln (\text { gross earnings from work last month })_{i t}$} & $\begin{array}{l}\text { Log of gross wage of } \\
\text { individual } i \text { in wave } t\end{array}$ \\
\hline$r_{a n k}$ & $\operatorname{rank}_{i t, p o s}=\frac{\operatorname{rank}_{i t, p o s}-1}{\operatorname{rank}_{t, p o s}^{m a x}-1}$ & $\operatorname{rank}_{i t, p o s, f s i z e}=\frac{\operatorname{rank}_{i t, p o s, f s i z e}-1}{\operatorname{rank}_{t, p o s, f s i z e}^{-1}}$ & $\begin{array}{l}\text { Rank of worker } i \text { in } \\
\text { period } t . \quad \text { Average } \\
\text { ranks are calculated } \\
\text { for workers with iden- } \\
\text { tical wages }\end{array}$ \\
\hline range $_{i t}$ & range $_{i t, \text { pos }}=\frac{w_{i t}-w_{t, p \text { pos }}^{\min }}{w_{t, p o s}^{m a x}-w_{t, p o s}^{m i n}}$ & range $_{i t, p o s, f s i z e}=\frac{w_{i t}-w_{t, p o s, f s i z e}^{\min }}{w_{t, p o s, f s i z e}^{m a x}-w_{t, p o s, f s i z e}^{\text {mmin}}}$ & Range of worker $i$ in $t$ \\
\hline
\end{tabular}


Table 4: Descriptive statistics

\begin{tabular}{|c|c|c|c|c|}
\hline Variables & Mean & $\begin{array}{l}\text { Standard } \\
\text { deviation }\end{array}$ & Minimum & Maximum \\
\hline Propensity to become self-employed $_{i t}$ & 8.925 & 18.426 & 0 & 100 \\
\hline $\operatorname{rank}_{i t, p o s}$ & 0.500 & 0.289 & 0 & 1 \\
\hline$r a n k_{i t, p o s}^{2}$ & 0.334 & 0.299 & 0 & 1 \\
\hline rank $_{i t, p o s, f s i z e}$ & 0.500 & 0.292 & 0 & 1 \\
\hline $\operatorname{rank}_{i t, p o s, f \text { size }}^{2}$ & 0.335 & 0.302 & 0 & 1 \\
\hline range $_{i t, p o s}$ & 0.576 & 0.150 & 0 & 1 \\
\hline range $_{i t, p o s}^{2}$ & 0.345 & 0.167 & 0 & 1 \\
\hline range $_{i t, p o s, f s i z e}$ & 0.572 & 0.181 & 0 & 1 \\
\hline range $_{i t, p o s, f s i z e}^{2}$ & 0.360 & 0.200 & 0 & 1 \\
\hline Low position $_{i t}$ & 0.0879 & 0.283 & 0 & 1 \\
\hline Medium position $_{i t}$ & 0.578 & 0.494 & 0 & 1 \\
\hline High position $_{i t}$ & 0.334 & 0.472 & 0 & 1 \\
\hline$w_{i t}$ & 7.818 & 0.493 & 5.991 & 9.865 \\
\hline Workforce $_{i t}<20$ & 0.218 & 0.413 & 0 & 1 \\
\hline Workforce $_{i t} \in[20 ; 200[$ & 0.307 & 0.461 & 0 & 1 \\
\hline Workforce $_{i t} \in[200 ; 2000[$ & 0.231 & 0.421 & 0 & 1 \\
\hline Workforce $_{i t} \geq 2000$ & 0.244 & 0.430 & 0 & 1 \\
\hline Tenure $_{i t}$ & 8.664 & 8.881 & 0 & 40.500 \\
\hline Tenure $_{i t}^{2}$ & 153.936 & 256.310 & 0 & 1640.250 \\
\hline $\mathrm{Age}_{i t}$ & 39.084 & 9.275 & 19 & 55 \\
\hline $\operatorname{Age}_{i t}^{2}$ & 1613.599 & 715.804 & 361 & 3025 \\
\hline ISCED $1_{i t}$ & 0.00680 & 0.0822 & 0 & 1 \\
\hline $\mathrm{ISCED}_{i t}$ & 0.0618 & 0.241 & 0 & 1 \\
\hline $\mathrm{ISCED}_{i t}$ & 0.544 & 0.498 & 0 & 1 \\
\hline $\mathrm{ISCED}_{i t}$ & 0.0704 & 0.256 & 0 & 1 \\
\hline ISCED $5_{i t}$ & 0.0903 & 0.287 & 0 & 1 \\
\hline ISCED $_{i t}$ & 0.227 & 0.419 & 0 & 1 \\
\hline Blue-collar worker ${ }_{i t}$ & 0.477 & 0.499 & 0 & 1 \\
\hline White-collar worker $_{i t}$ & 0.523 & 0.499 & 0 & 1 \\
\hline Working hours $\leq 29_{i t}^{1)}$ & 0.0283 & 0.166 & 0 & 1 \\
\hline Working hours $\in] 29 ; 35]_{i t}^{1)}$ & 0.0849 & 0.279 & 0 & 1 \\
\hline Working hours $>35_{i t}^{1)}$ & 0.887 & 0.317 & 0 & 1 \\
\hline Regional unemployment rate growth $t$ & -0.538 & 1.154 & 0 & 1 \\
\hline Single $_{i t}$ & 0.332 & 0.471 & 0 & 1 \\
\hline Married $_{i t}^{2)}$ & 0.575 & 0.494 & 0 & 1 \\
\hline Other marital statuses $_{i t}$ & 0.0933 & 0.291 & 0 & 1 \\
\hline Year: 1999 & 0.0548 & 0.228 & 0 & 1 \\
\hline Year: 2001 & 0.0741 & 0.262 & 0 & 1 \\
\hline
\end{tabular}


Year: 2003

\begin{tabular}{cccc}
0.0517 & 0.221 & 0 & 1 \\
0.0478 & 0.213 & 0 & 1 \\
0.390 & 0.488 & 0 & 1 \\
0.381 & 0.486 & 0 & 1 \\
0.135 & 0.341 & 0 & 1 \\
0.274 & 0.446 & 0 & 1 \\
0.276 & 0.447 & 0 & 1 \\
0.316 & 0.465 & 0 & 1 \\
\hline & & & \\
\hline
\end{tabular}

Year: 2005

Year: 2007

Year: 2009

North Germany ${ }^{3)}$

East Germany ${ }_{i t}^{4}$

$y_{\text {it }}^{4)}$

South Germany ${ }_{i t}^{5)}$

Number of observations

Number of individuals

1) Contractual working hours.

2) Married, spouse present.

3) Bremen, Hamburg, Lower Saxony, and Schleswig-Holstein.

4) Berlin, Brandenburg, Mecklenburg-Western Pomerania, Saxony, Saxony-Anhalt, and Thuringia.

5) Bavaria and Baden-Wuerttemberg.

6) Hesse, North Rhine-Westphalia, Rhineland-Palatinate, and Saarland. 
Table 5: Individual random-effects ordered probit results: Hypothesis 1.

\begin{tabular}{|c|c|c|c|c|}
\hline Variables & 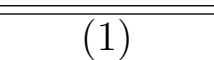 & $\overline{(2)}$ & $(3)$ & $(4)$ \\
\hline rank $_{i t, p o s}$ & $\begin{array}{l}-0.317 \\
(0.249)\end{array}$ & & & \\
\hline $\operatorname{rank}_{i t, p o s, f s i z e}$ & & $\begin{array}{r}-0.0996 \\
(0.205)\end{array}$ & & \\
\hline range $_{i t, p o s}$ & & & $\begin{array}{l}-0.360 \\
(0.489)\end{array}$ & \\
\hline range $_{i t, p o s, f s i z e}$ & & & & $\begin{array}{l}-0.207 \\
(0.256)\end{array}$ \\
\hline Low position $i t$ & $\begin{array}{r}-0.0395 \\
(0.157)\end{array}$ & $\begin{array}{l}-0.149 \\
(0.139)\end{array}$ & $\begin{array}{r}-0.0859 \\
(0.180)\end{array}$ & $\begin{array}{l}-0.122 \\
(0.134)\end{array}$ \\
\hline Medium position $_{i t}$ & $\begin{array}{l}-0.105 \\
(0.101)\end{array}$ & $\begin{array}{r}-0.177^{* *} \\
(0.0882)\end{array}$ & $\begin{array}{l}-0.134 \\
(0.118)\end{array}$ & $\begin{array}{l}-0.162^{*} \\
(0.0832)\end{array}$ \\
\hline Reference: High position $i t$ & & & & \\
\hline Workforce $_{i t}<20$ & $\begin{array}{c}0.449^{* * *} \\
(0.0721)\end{array}$ & $\begin{array}{c}0.482^{* * *} \\
(0.0929)\end{array}$ & $\begin{array}{c}0.456^{* * *} \\
(0.0721)\end{array}$ & $\begin{array}{c}0.475^{* * *} \\
(0.0767)\end{array}$ \\
\hline Workforce $_{i t} \in[20 ; 200[$ & $\begin{array}{l}0.144^{* *} \\
(0.0640)\end{array}$ & $\begin{array}{l}0.167^{* *} \\
(0.0738)\end{array}$ & $\begin{array}{l}0.150^{* *} \\
(0.0639)\end{array}$ & $\begin{array}{l}0.154^{* *} \\
(0.0643)\end{array}$ \\
\hline Workforce $_{i t} \in[200 ; 2000[$ & $\begin{array}{c}0.168^{* * *} \\
(0.0642)\end{array}$ & $\begin{array}{c}0.176^{* * *} \\
(0.0663)\end{array}$ & $\begin{array}{c}0.170^{* * *} \\
(0.0643)\end{array}$ & $\begin{array}{c}0.167^{* * *} \\
(0.0642)\end{array}$ \\
\hline Reference: Workforce $_{i t} \geq 200$ & & & & \\
\hline$w_{i t}$ & $\begin{array}{c}0.364^{* *} \\
(0.174)\end{array}$ & $\begin{array}{c}0.230 \\
(0.155)\end{array}$ & $\begin{array}{c}0.287 \\
(0.183)\end{array}$ & $\begin{array}{l}0.248^{*} \\
(0.128)\end{array}$ \\
\hline $\begin{array}{l}\text { Additional control variables } \\
\text { (see Table A.1) }\end{array}$ & \multicolumn{4}{|c|}{ included } \\
\hline Rho & $\begin{array}{c}0.510^{* * *} \\
(0.0223)\end{array}$ & $\begin{array}{c}0.511^{* * *} \\
(0.0223)\end{array}$ & $\begin{array}{c}0.511^{* * *} \\
(0.0223)\end{array}$ & $\begin{array}{c}0.511^{* * *} \\
(0.0223)\end{array}$ \\
\hline Log likelihood & -8002.2467 & -8002.9418 & -8002.7893 & -8002.7351 \\
\hline Number of observations & \multicolumn{4}{|c|}{7,211} \\
\hline
\end{tabular}

Standard errors in parentheses.

*** $\mathrm{p}<0.01,{ }^{* *} \mathrm{p}<0.05,{ }^{*} \mathrm{p}<0.1$. 
Table 6: Individual random-effects ordered probit results: Hypothesis 2.

\begin{tabular}{|c|c|c|c|c|}
\hline Variables & $(1)$ & $(2)$ & $(3)$ & $(4)$ \\
\hline rank $_{i t, p o s}$ & $\begin{array}{c}-1.559^{* * *} \\
(0.425)\end{array}$ & & & \\
\hline $\operatorname{rank}_{i t, p o s}^{2}$ & $\begin{array}{c}1.071^{* * *} \\
(0.297)\end{array}$ & & & \\
\hline$r a n k_{i t, p o s, f s i z e}$ & & $\begin{array}{c}-0.829^{* *} \\
(0.374)\end{array}$ & & \\
\hline $\operatorname{rank}_{i t, p o s, f s i z e}^{2}$ & & $\begin{array}{c}0.665^{* *} \\
(0.286)\end{array}$ & & \\
\hline range $_{i t, p o s}$ & & & $\begin{array}{c}-2.019 * * \\
(0.839)\end{array}$ & \\
\hline range $_{i t, p o s}^{2}$ & & & $\begin{array}{c}1.383^{* *} \\
(0.569)\end{array}$ & \\
\hline range $_{i t, p o s, f s i z e}$ & & & & $\begin{array}{c}-1.888^{* * *} \\
(0.511)\end{array}$ \\
\hline range $_{i t, p o s, f s i z e}^{2}$ & & & & $\begin{array}{c}1.575^{* * *} \\
(0.414)\end{array}$ \\
\hline Low position $_{i t}$ & $\begin{array}{l}0.0495 \\
(0.158)\end{array}$ & $\begin{array}{l}-0.118 \\
(0.139)\end{array}$ & $\begin{array}{r}-0.0582 \\
(0.180)\end{array}$ & $\begin{array}{l}-0.166 \\
(0.135)\end{array}$ \\
\hline Medium position $_{i t}$ & $\begin{array}{r}-0.0580 \\
(0.101)\end{array}$ & $\begin{array}{l}-0.163^{*} \\
(0.0883)\end{array}$ & $\begin{array}{l}-0.104 \\
(0.119)\end{array}$ & $\begin{array}{c}-0.174^{* *} \\
(0.0833)\end{array}$ \\
\hline Reference: High position $i t$ & & & & \\
\hline Workforce $_{i t}<20$ & $\begin{array}{l}0.441^{* * *} \\
(0.0722)\end{array}$ & $\begin{array}{l}0.500^{* * *} \\
(0.0932)\end{array}$ & $\begin{array}{l}0.458^{* * *} \\
(0.0722)\end{array}$ & $\begin{array}{c}0.476^{* * *} \\
(0.0770)\end{array}$ \\
\hline Workforce $_{i t} \in[20 ; 200[$ & $\begin{array}{l}0.149 * * \\
(0.0641)\end{array}$ & $\begin{array}{l}0.179 * * \\
(0.0740)\end{array}$ & $\begin{array}{l}0.154^{* *} \\
(0.0641)\end{array}$ & $\begin{array}{l}0.161^{* *} \\
(0.0646)\end{array}$ \\
\hline Workforce $_{i t} \in[200 ; 2000[$ & $\begin{array}{c}0.173^{* * *} \\
(0.0643)\end{array}$ & $\begin{array}{c}0.181 * * * \\
(0.0664)\end{array}$ & $\begin{array}{c}0.168^{* * *} \\
(0.0644)\end{array}$ & $\begin{array}{l}0.166^{* *} \\
(0.0645)\end{array}$ \\
\hline \multicolumn{5}{|c|}{ Reference: Workforce $i t \geq 2000$} \\
\hline$w_{i t}$ & $\begin{array}{c}0.471^{* * *} \\
(0.176)\end{array}$ & $\begin{array}{l}0.269^{*} \\
(0.156)\end{array}$ & $\begin{array}{l}0.349^{*} \\
(0.185)\end{array}$ & $\begin{array}{l}0.246^{*} \\
(0.128)\end{array}$ \\
\hline $\begin{array}{l}\text { Additional control variables } \\
\text { (see Table A.2) }\end{array}$ & \multicolumn{4}{|c|}{ included } \\
\hline Rho & $\begin{array}{c}0.511^{* * *} \\
(0.0222)\end{array}$ & $\begin{array}{c}0.511^{* * *} \\
(0.0223)\end{array}$ & $\begin{array}{c}0.512^{* * *} \\
(0.0223)\end{array}$ & $\begin{array}{c}0.514^{* * *} \\
(0.0223)\end{array}$ \\
\hline Log likelihood & -7995.7226 & -8000.2204 & -7999.8477 & -7995.4979 \\
\hline Number of observations & \multicolumn{4}{|c|}{7,211} \\
\hline
\end{tabular}

Standard errors in parentheses.

*** $\mathrm{p}<0.01, * * \mathrm{p}<0.05,{ }^{*} \mathrm{p}<0.1$. 


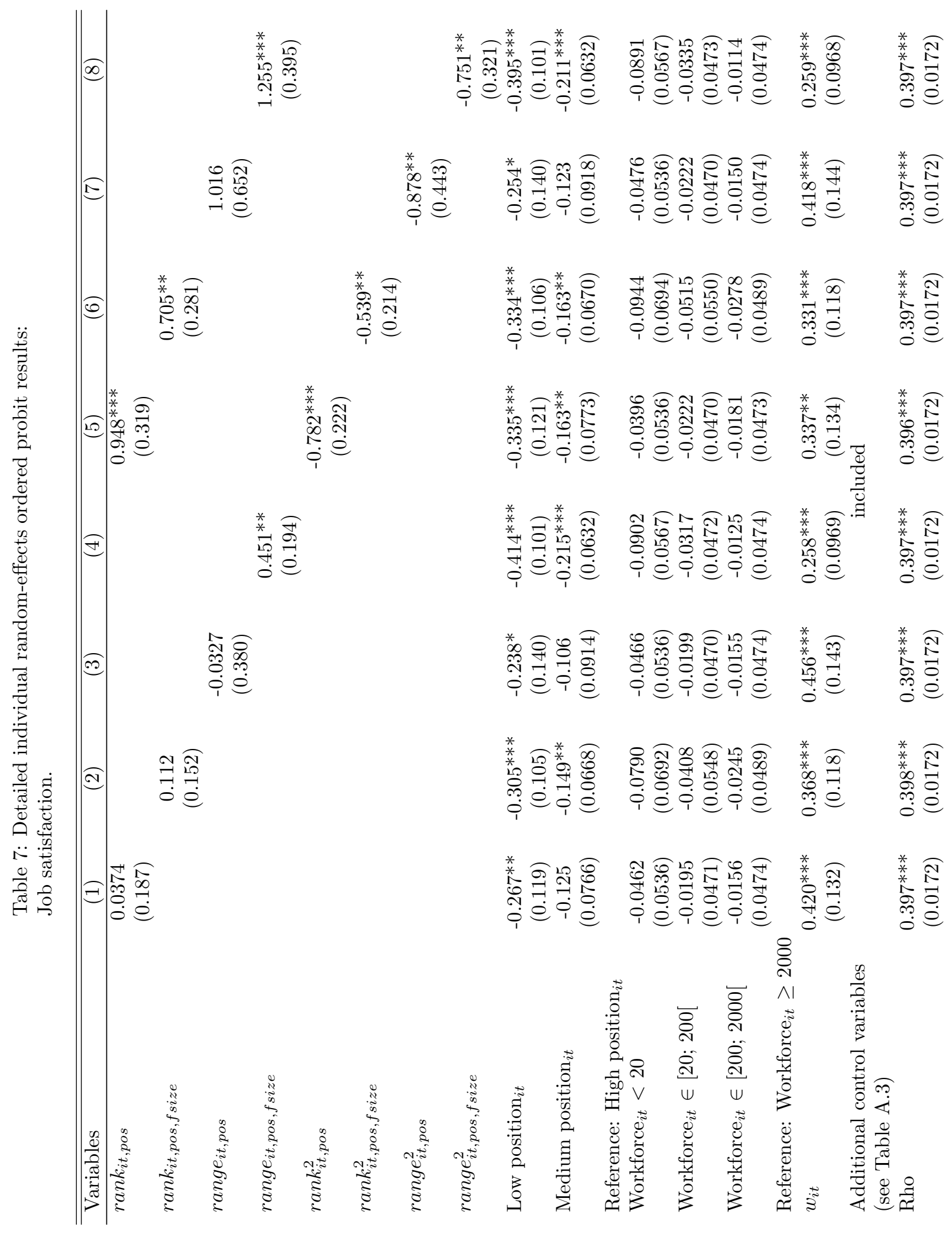




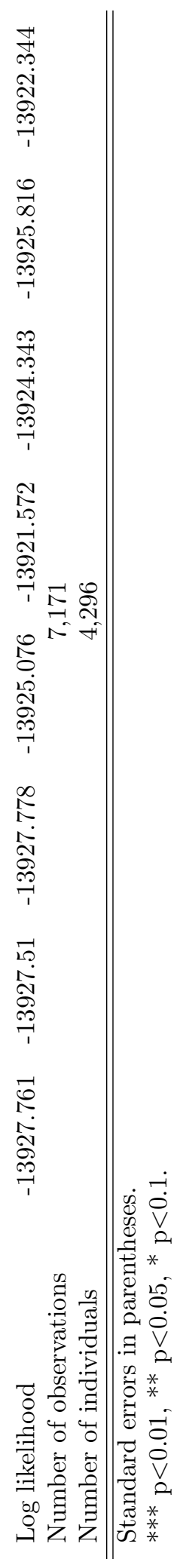




\section{Figures included in the text}

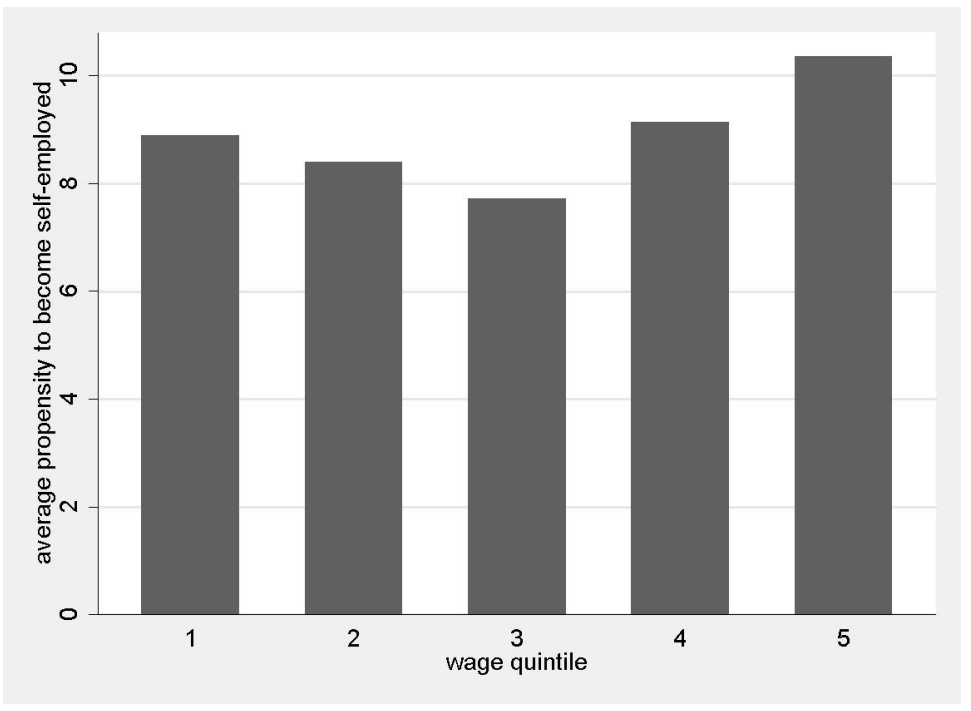

Figure 1: Become self-employed within the next two years by wage quintiles. 


\section{Appendix}

Table A.1: Detailed individual random-effects ordered probit results: Hypothesis 1.

\begin{tabular}{|c|c|c|c|c|}
\hline Variables & $(1)$ & $(2)$ & (3) & $(4)$ \\
\hline rank $_{i t, p o s}$ & $\begin{array}{l}-0.317 \\
(0.249)\end{array}$ & & & \\
\hline$r a n k_{i t, p o s, f s i z e}$ & & $\begin{array}{l}-0.0996 \\
(0.205)\end{array}$ & & \\
\hline range $_{i t, p o s}$ & & & $\begin{array}{l}-0.360 \\
(0.489)\end{array}$ & \\
\hline range $_{i t, p o s, f s i z e}$ & & & & $\begin{array}{l}-0.207 \\
(0.256)\end{array}$ \\
\hline Low position $_{i t}$ & $\begin{array}{l}-0.0395 \\
(0.157)\end{array}$ & $\begin{array}{l}-0.149 \\
(0.139)\end{array}$ & $\begin{array}{r}-0.0859 \\
(0.180)\end{array}$ & $\begin{array}{l}-0.122 \\
(0.134)\end{array}$ \\
\hline Medium position $_{i t}$ & $\begin{array}{l}-0.105 \\
(0.101)\end{array}$ & $\begin{array}{c}-0.177^{* *} * \\
(0.0882)\end{array}$ & $\begin{array}{l}-0.134 \\
(0.118)\end{array}$ & $\begin{array}{l}-0.162^{*} \\
(0.0832)\end{array}$ \\
\hline Reference: High position $i t$ & & & & \\
\hline Workforce $_{i t}<20$ & $\begin{array}{c}0.449^{* * *} \\
(0.0721)\end{array}$ & $\begin{array}{r}0.482^{* * *} \\
(0.0929)\end{array}$ & $\begin{array}{c}0.456^{* * *} \\
(0.0721)\end{array}$ & $\begin{array}{c}0.475^{* * *} \\
(0.0767)\end{array}$ \\
\hline Workforce $_{i t} \in[20 ; 200[$ & $\begin{array}{l}0.144^{* *} \\
(0.0640)\end{array}$ & $\begin{array}{l}0.167^{* *} \\
(0.0738)\end{array}$ & $\begin{array}{l}0.150^{* *} \\
(0.0639)\end{array}$ & $\begin{array}{l}0.154^{* *} \\
(0.0643)\end{array}$ \\
\hline Workforce $_{i t} \in[200 ; 2000[$ & $\begin{array}{c}0.168^{* * *} \\
(0.0642)\end{array}$ & $\begin{array}{c}0.176^{* * *} \\
(0.0663)\end{array}$ & $\begin{array}{c}0.170^{* * *} \\
(0.0643)\end{array}$ & $\begin{array}{c}0.167^{* * *} \\
(0.0642)\end{array}$ \\
\hline Reference: Workforce $i t \geq 2000$ & & & & \\
\hline$w_{i t}$ & $\begin{array}{c}0.364^{* *} \\
(0.174)\end{array}$ & $\begin{array}{c}0.230 \\
(0.155)\end{array}$ & $\begin{array}{c}0.287 \\
(0.183)\end{array}$ & $\begin{array}{l}0.248^{*} \\
(0.128)\end{array}$ \\
\hline $\operatorname{Age}_{i t}$ & $\begin{array}{c}0.0242 \\
(0.0226)\end{array}$ & $\begin{array}{c}0.0236 \\
(0.0226)\end{array}$ & $\begin{array}{c}0.0245 \\
(0.0226)\end{array}$ & $\begin{array}{c}0.0243 \\
(0.0226)\end{array}$ \\
\hline $\operatorname{Age}_{i t}^{2}$ & $\begin{array}{c}-0.000692^{* *} \\
(0.000288)\end{array}$ & $\begin{array}{c}-0.000685^{* *} \\
(0.000288)\end{array}$ & $\begin{array}{c}-0.000698^{* *} \\
(0.000288)\end{array}$ & $\begin{array}{c}-0.000695^{* *} \\
(0.000288)\end{array}$ \\
\hline Tenure $_{i t}$ & $\begin{array}{c}-0.0109 \\
(0.00898)\end{array}$ & $\begin{array}{c}-0.0112 \\
(0.00899)\end{array}$ & $\begin{array}{c}-0.0116 \\
(0.00898)\end{array}$ & $\begin{array}{c}-0.0116 \\
(0.00899)\end{array}$ \\
\hline Tenure $_{i t}^{2}$ & $\begin{array}{c}1.98 \mathrm{e}-05 \\
(0.000306)\end{array}$ & $\begin{array}{c}2.04 \mathrm{e}-05 \\
(0.000306)\end{array}$ & $\begin{array}{c}2.97 \mathrm{e}-05 \\
(0.000306)\end{array}$ & $\begin{array}{c}3.10 \mathrm{e}-05 \\
(0.000307)\end{array}$ \\
\hline ISCED $2_{i t}$ & $\begin{array}{l}-0.185 \\
(0.295)\end{array}$ & $\begin{array}{l}-0.187 \\
(0.295)\end{array}$ & $\begin{array}{l}-0.188 \\
(0.295)\end{array}$ & $\begin{array}{l}-0.188 \\
(0.295)\end{array}$ \\
\hline $\mathrm{ISCED}_{i t}$ & $\begin{array}{l}-0.282 \\
(0.283)\end{array}$ & $\begin{array}{l}-0.281 \\
(0.283)\end{array}$ & $\begin{array}{l}-0.283 \\
(0.283)\end{array}$ & $\begin{array}{l}-0.283 \\
(0.284)\end{array}$ \\
\hline $\mathrm{ISCED}_{i t}$ & -0.0965 & -0.0989 & -0.0998 & -0.101 \\
\hline
\end{tabular}




\begin{tabular}{|c|c|c|c|c|}
\hline & $(0.296)$ & $(0.296)$ & $(0.297)$ & $(0.297)$ \\
\hline \multirow[t]{2}{*}{ ISCED $5_{i t}$} & 0.131 & 0.129 & 0.129 & 0.127 \\
\hline & $(0.294)$ & $(0.294)$ & $(0.294)$ & $(0.294)$ \\
\hline \multirow[t]{2}{*}{ ISCED $_{i t}$} & 0.109 & 0.108 & 0.104 & 0.106 \\
\hline & $(0.292)$ & $(0.292)$ & $(0.292)$ & $(0.293)$ \\
\hline \multicolumn{5}{|l|}{ Reference: ISCED $1_{i t}$} \\
\hline Blue-collar worker $_{i t}$ & $\begin{array}{c}-0.321^{* * *} \\
(0.0610)\end{array}$ & $\begin{array}{c}-0.316^{* * *} \\
(0.0610)\end{array}$ & $\begin{array}{c}-0.315^{* * *} \\
(0.0608)\end{array}$ & $\begin{array}{c}-0.313^{* * *} \\
(0.0608)\end{array}$ \\
\hline \multicolumn{5}{|l|}{ Reference: White-collar worker ${ }_{i t}$} \\
\hline \multirow[t]{2}{*}{ Working hours $\leq 29_{i t}$} & $0.333^{* *}$ & $0.316^{* *}$ & $0.299 * *$ & $0.300^{* *}$ \\
\hline & $(0.135)$ & $(0.135)$ & $(0.133)$ & $(0.133)$ \\
\hline \multirow{2}{*}{ Working hours $\in] 29 ; 35]_{i t}$} & 0.0250 & 0.0230 & 0.0224 & 0.0221 \\
\hline & $(0.0816)$ & $(0.0816)$ & $(0.0816)$ & $(0.0816)$ \\
\hline \multicolumn{5}{|l|}{ Reference: Working hours $>35_{i t}$} \\
\hline \multirow[t]{2}{*}{ Regional unemployment growth } & 0.0437 & 0.0454 & 0.0431 & 0.0417 \\
\hline & $(0.0628)$ & $(0.0628)$ & $(0.0629)$ & $(0.0630)$ \\
\hline \multirow[t]{2}{*}{ Single $_{i t}$} & -0.0417 & -0.0420 & -0.0426 & -0.0432 \\
\hline & $(0.0962)$ & $(0.0963)$ & $(0.0963)$ & $(0.0963)$ \\
\hline \multirow[t]{2}{*}{ Married $_{i t}$} & 0.0206 & 0.0208 & 0.0196 & 0.0190 \\
\hline & $(0.0830)$ & $(0.0830)$ & $(0.0830)$ & $(0.0831)$ \\
\hline \multicolumn{5}{|l|}{ Reference: Other marital statuses $i t$} \\
\hline \multirow{2}{*}{\multicolumn{2}{|c|}{$\begin{array}{l}\text { Annual dummy variables } \\
\text { Regional dummy variables }\end{array}$}} & \multicolumn{2}{|c|}{ included } & \\
\hline & & \multicolumn{2}{|c|}{ included } & \\
\hline \multirow[t]{2}{*}{ Rho } & $0.510^{* * *}$ & $0.511^{* * *}$ & $0.511^{* * *}$ & $0.511^{* * *}$ \\
\hline & $(0.0223)$ & $(0.0223)$ & $(0.0223)$ & $(0.0223)$ \\
\hline Log likelihood & -8002.2467 & -8002.9418 & -8002.7893 & -8002.7351 \\
\hline \multicolumn{2}{|l|}{ Number of observations } & \multicolumn{2}{|c|}{7,211} & \\
\hline
\end{tabular}

Standard errors in parentheses.

$* * * \mathrm{p}<0.01,{ }^{*} * \mathrm{p}<0.05,{ }^{*} \mathrm{p}<0.1$.

Estimated thresholds are not shown for ease of presentation. Available upon request.

Table A.2: Detailed individual random-effects ordered probit results: Hypothesis 2.

\begin{tabular}{lccc}
\hline \hline Variables & $(1)$ & $(2)$ & $(3)$ \\
\hline rank $_{i t, \text { pos }}$ & $-1.559^{* * *}$ & & \\
& $(0.425)$ & & \\
rank $_{i t, \text { pos }}^{2}$ & $1.071^{* * *}$ & & \\
rank $_{i t, \text { pos }, \text { size }}$ & $(0.297)$ & & \\
& & $-0.829^{* *}$ & \\
& & $(0.374)$
\end{tabular}




\begin{tabular}{|c|c|c|c|c|}
\hline$r a n k_{i t, p o s, f s i z e}^{2}$ & & $\begin{array}{c}0.665^{* *} \\
(0.286)\end{array}$ & & \\
\hline range $_{i t, p o s}$ & & & $\begin{array}{c}-2.019^{* *} \\
(0.839)\end{array}$ & \\
\hline range $_{i t, p o s}^{2}$ & & & $\begin{array}{l}1.383^{* *} \\
(0.569)\end{array}$ & \\
\hline range $_{i t, p o s, f s i z e}$ & & & & $\begin{array}{c}-1.888^{* * *} \\
(0.511)\end{array}$ \\
\hline range $_{i t, p o s, f s i z e}^{2}$ & & & & $\begin{array}{c}1.575^{* * *} \\
(0.414)\end{array}$ \\
\hline Low position $_{i t}$ & $\begin{array}{l}0.0495 \\
(0.158)\end{array}$ & $\begin{array}{l}-0.118 \\
(0.139)\end{array}$ & $\begin{array}{c}-0.0582 \\
(0.180)\end{array}$ & $\begin{array}{l}-0.166 \\
(0.135)\end{array}$ \\
\hline Medium position $_{i t}$ & $\begin{array}{c}-0.0580 \\
(0.101)\end{array}$ & $\begin{array}{l}-0.163^{*} \\
(0.0883)\end{array}$ & $\begin{array}{l}-0.104 \\
(0.119)\end{array}$ & $\begin{array}{c}-0.174^{* *} \\
(0.0833)\end{array}$ \\
\hline Reference: High position $i t$ & & & & \\
\hline Workforce $_{i t}<20$ & $\begin{array}{c}0.441^{* * *} \\
(0.0722)\end{array}$ & $\begin{array}{c}0.500^{* * *} \\
(0.0932)\end{array}$ & $\begin{array}{c}0.458^{* * *} \\
(0.0722)\end{array}$ & $\begin{array}{c}0.476^{* * *} \\
(0.0770)\end{array}$ \\
\hline Workforce $_{i t} \in[20 ; 200[$ & $\begin{array}{l}0.149 * * \\
(0.0641)\end{array}$ & $\begin{array}{l}0.179 * * \\
(0.0740)\end{array}$ & $\begin{array}{l}0.154^{* *} \\
(0.0641)\end{array}$ & $\begin{array}{l}0.161^{* *} \\
(0.0646)\end{array}$ \\
\hline Workforce $_{i t} \in[200 ; 2000[$ & $\begin{array}{c}0.173 * * * \\
(0.0643)\end{array}$ & $\begin{array}{c}0.181^{* * *} \\
(0.0664)\end{array}$ & $\begin{array}{c}0.168^{* * *} \\
(0.0644)\end{array}$ & $\begin{array}{l}0.166^{* *} \\
(0.0645)\end{array}$ \\
\hline Reference: Workforce $_{i t} \geq 2000$ & & & & \\
\hline$w_{i t}$ & $\begin{array}{c}0.471^{* * *} \\
(0.176)\end{array}$ & $\begin{array}{l}0.269^{*} \\
(0.156)\end{array}$ & $\begin{array}{l}0.349^{*} \\
(0.185)\end{array}$ & $\begin{array}{l}0.246^{*} \\
(0.128)\end{array}$ \\
\hline Age $_{i t}$ & $\begin{array}{c}0.0284 \\
(0.0226)\end{array}$ & $\begin{array}{c}0.0262 \\
(0.0226)\end{array}$ & $\begin{array}{c}0.0264 \\
(0.0226)\end{array}$ & $\begin{array}{c}0.0262 \\
(0.0227)\end{array}$ \\
\hline $\operatorname{Age}_{i t}^{2}$ & $\begin{array}{c}-0.000755^{* * *} \\
(0.000289)\end{array}$ & $\begin{array}{c}-0.000725^{* *} \\
(0.000288)\end{array}$ & $\begin{array}{c}-0.000727^{* *} \\
(0.000289)\end{array}$ & $\begin{array}{c}-0.000728^{* *} \\
(0.000289)\end{array}$ \\
\hline Tenure $_{i t}$ & $\begin{array}{c}-0.00980 \\
(0.00900)\end{array}$ & $\begin{array}{c}-0.0106 \\
(0.00900)\end{array}$ & $\begin{array}{c}-0.0118 \\
(0.00899)\end{array}$ & $\begin{array}{c}-0.0116 \\
(0.00901)\end{array}$ \\
\hline Tenure $_{i t}^{2}$ & $\begin{array}{c}1.67 \mathrm{e}-06 \\
(0.000306)\end{array}$ & $\begin{array}{c}1.42 \mathrm{e}-05 \\
(0.000306)\end{array}$ & $\begin{array}{c}3.72 \mathrm{e}-05 \\
(0.000307)\end{array}$ & $\begin{array}{c}3.35 \mathrm{e}-05 \\
(0.000307)\end{array}$ \\
\hline ISCED $2_{i t}$ & $\begin{array}{l}-0.173 \\
(0.295)\end{array}$ & $\begin{array}{l}-0.175 \\
(0.295)\end{array}$ & $\begin{array}{l}-0.193 \\
(0.295)\end{array}$ & $\begin{array}{l}-0.179 \\
(0.296)\end{array}$ \\
\hline ISCED $_{i t}$ & $\begin{array}{l}-0.261 \\
(0.283)\end{array}$ & $\begin{array}{l}-0.264 \\
(0.284)\end{array}$ & $\begin{array}{l}-0.288 \\
(0.284)\end{array}$ & $\begin{array}{l}-0.275 \\
(0.284)\end{array}$ \\
\hline $\mathrm{ISCED}_{i t}$ & $\begin{array}{c}-0.0790 \\
(0.297)\end{array}$ & $\begin{array}{c}-0.0832 \\
(0.297)\end{array}$ & $\begin{array}{l}-0.106 \\
(0.297)\end{array}$ & $\begin{array}{r}-0.0951 \\
(0.298)\end{array}$ \\
\hline $\mathrm{ISCED}_{i t}$ & $\begin{array}{c}0.147 \\
(0.294)\end{array}$ & $\begin{array}{c}0.149 \\
(0.294)\end{array}$ & $\begin{array}{c}0.119 \\
(0.294)\end{array}$ & $\begin{array}{c}0.135 \\
(0.295)\end{array}$ \\
\hline ISCED $_{i t}$ & $\begin{array}{c}0.130 \\
(0.292)\end{array}$ & $\begin{array}{c}0.128 \\
(0.293)\end{array}$ & $\begin{array}{l}0.0999 \\
(0.293)\end{array}$ & $\begin{array}{c}0.118 \\
(0.293)\end{array}$ \\
\hline
\end{tabular}


Reference: ISCED $1_{i t}$

Blue-collar worker $i t$

$\begin{array}{cccc}-0.316^{* * *} & -0.311^{* * *} & -0.306 * * * & -0.299^{* * *} \\ (0.0612) & (0.0611) & (0.0610) & (0.0611)\end{array}$

Reference: White-collar worker ${ }_{i t}$

Working hours $\leq 29_{i t}$

$\begin{array}{cccc}0.250^{*} & 0.260^{*} & 0.221 & 0.176 \\ (0.137) & (0.137) & (0.137) & (0.138) \\ 0.0110 & 0.0175 & 0.0177 & 0.0139 \\ (0.0818) & (0.0817) & (0.0817) & (0.0819)\end{array}$

Reference: Working hours $>35_{i t}$

Regional unemployment growth $\mathrm{g}_{t}$

$\begin{array}{cccc}0.0531 & 0.0511 & 0.0456 & 0.0471 \\ (0.0630) & (0.0629) & (0.0630) & (0.0632) \\ -0.0469 & -0.0460 & -0.0465 & -0.0490 \\ (0.0964) & (0.0964) & (0.0964) & (0.0967) \\ 0.0138 & 0.0177 & 0.0154 & 0.0141 \\ (0.0831) & (0.0831) & (0.0832) & (0.0833)\end{array}$

Reference: Other marital statuses $i t$ Annual dummy variables included

Regional dummy variables included

Rho

$0.511^{* * *}$

$0.511^{* * *}$

$0.512^{* * *}$

$0.514^{* * *}$

Log likelihood

(0.0222)

$(0.0223)$

(0.0223)

$(0.0223)$

Number of observations

Standard errors in parentheses.

*** $\mathrm{p}<0.01,{ }^{* *} \mathrm{p}<0.05,{ }^{*} \mathrm{p}<0.1$.

Estimated thresholds are not shown for ease of presentation. Available upon request. 


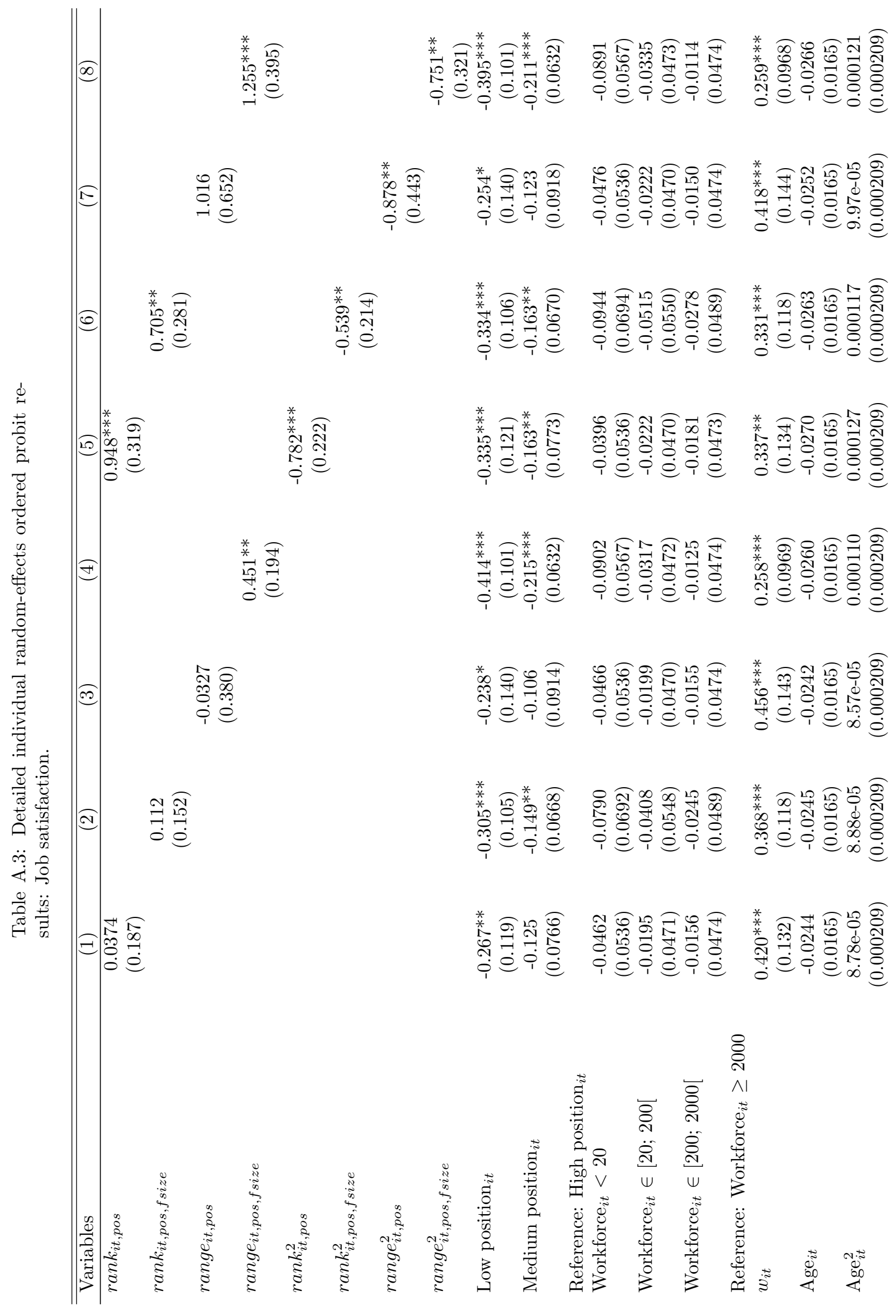




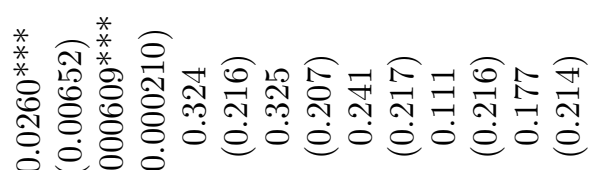
î.

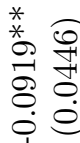

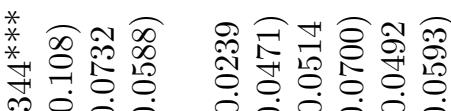

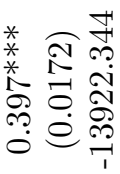

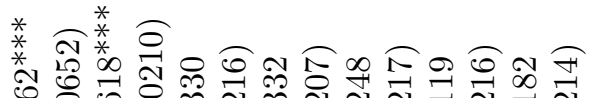

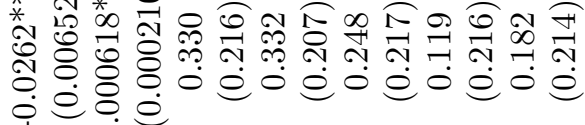

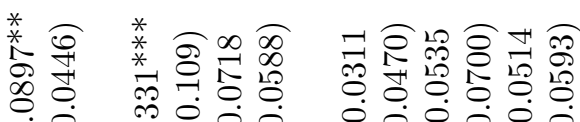

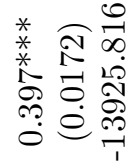

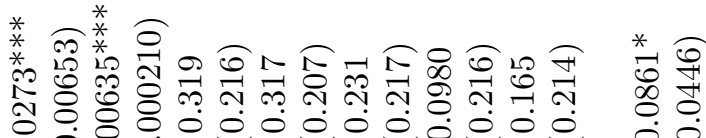

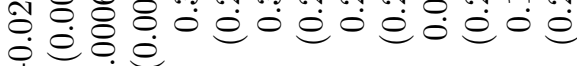

ţำ

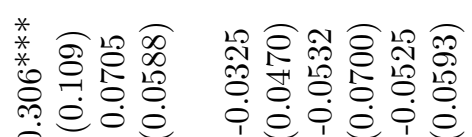

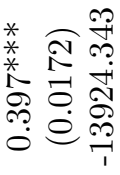

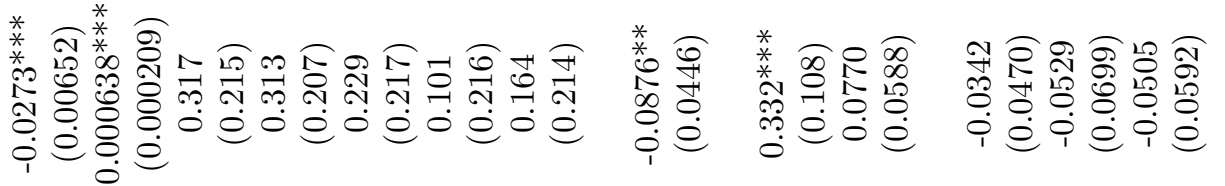

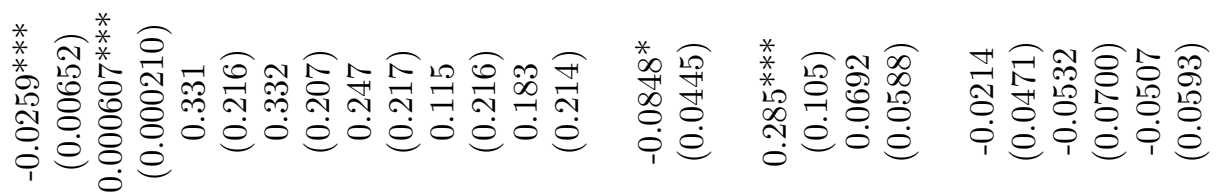

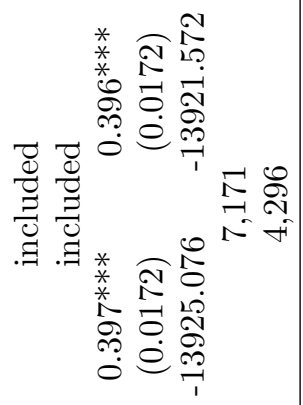

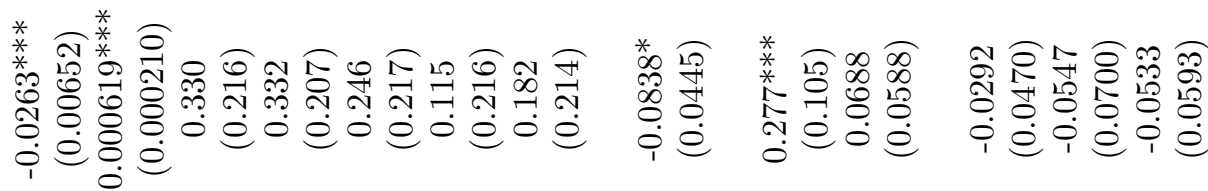

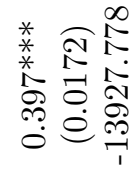

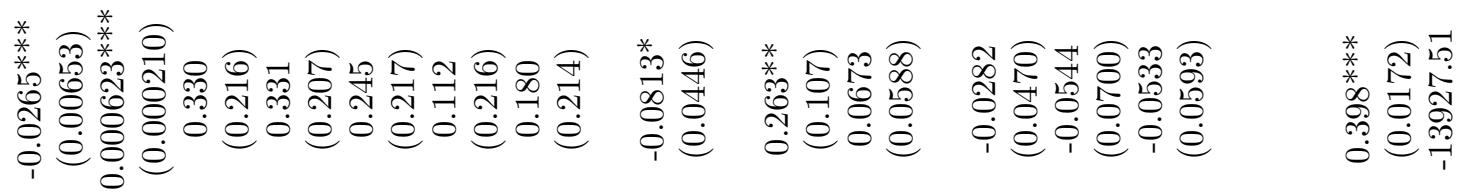

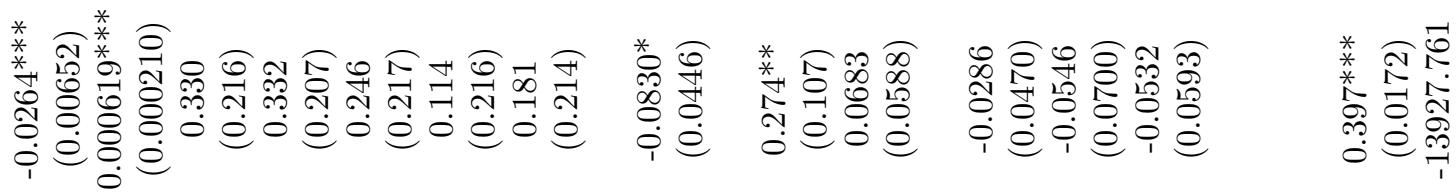

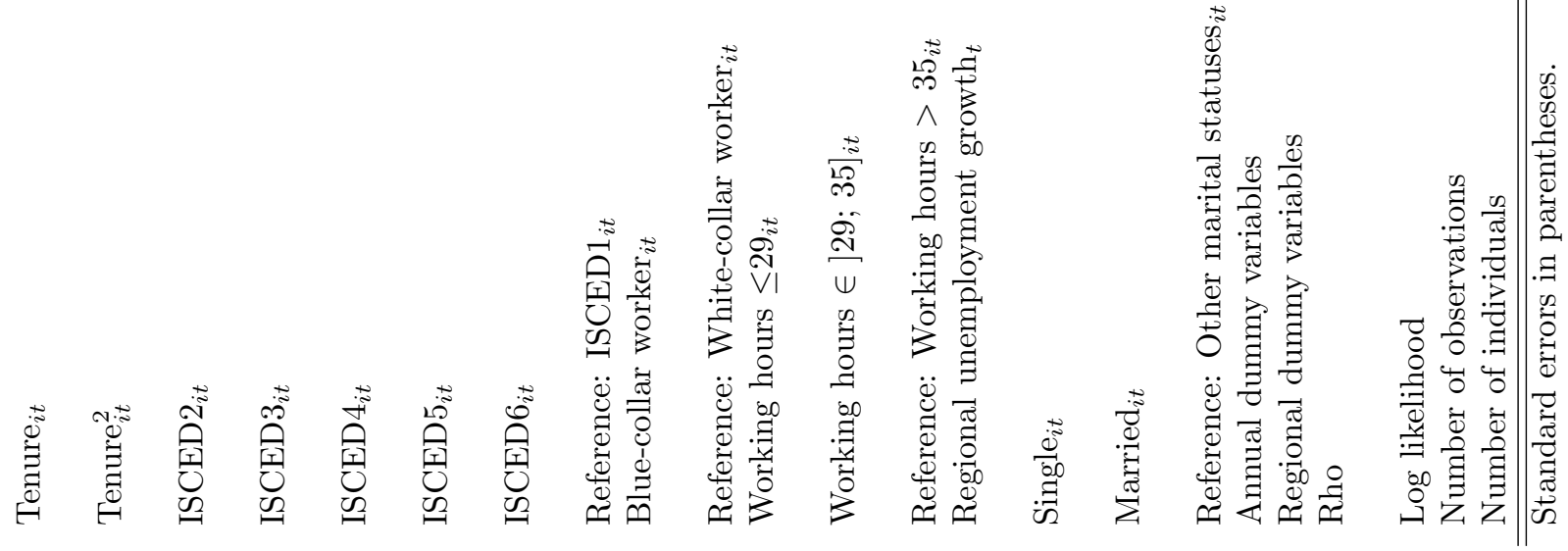




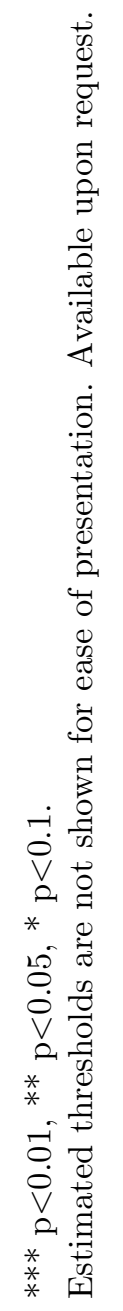

